\title{
Aplikasi Pendaftaran Ekstrakulikuler Online di Tingkat Sekolah Menengah Pertama (E-Ekskul)
}

\author{
Verra Sofica $^{1}$, Vivi Selesti Juliani ${ }^{2}$, Minda Septiani ${ }^{3}$, Rahayu Ningsih ${ }^{4}$ \\ ${ }^{1}$ Sekolah Tinggi Manajemen Informatika dan Komputer Nusa Mandiri \\ e-mail: ${ }^{1}$ verra.vsc@ nusamandiri.ac.id \\ 2,3,4 Universitas Bina Sarana Informatika \\ e-mail: ${ }^{2}$ viviselesti59@gmail.com, ${ }^{3}$ minda.mdt@bsi.ac.id, ${ }^{4}$ rahayu.ryh@bsi.ac.id

\begin{tabular}{ccc}
\hline Diterima & Direvisi & Disetujui \\
$21-02-2020$ & $28-04-2020$ & $20-05-2020$ \\
\hline
\end{tabular}

\begin{abstract}
Abstrak - Setiap sekolah pasti memiliki beragam macam kegiatan non-pelajaran formal atau biasa disebut ekstrakurikuler yang berguna untuk membentuk pribadi siswa itu sendiri. Ada banyak tujuan dari ekstrakulikuler di sekolah salah satunya mengembangkan bakat, minat, hobi serta ketrampilan siswa dalam upaya pembinaan pribadi menuju pembinaan manusia seutuhnya sehingga tercipta sumber daya manusia yang unggul dan handal. Selain itu jika kegiatan ektrakulikuler dapat ditekuni dengan sungguh-sungguh, tidak menutup kemungkinan prestasi bisa diraih oleh siswa dengan mengikuti lomba atau pun kejuaraan mulai tingkat lokal, nasional sampai dengan internasional. Perkembangan pendidikan sekolah dalam mengelola data siswa yang mengikuti pendaftaran kegiatan organisasi ekstrakurikuler setidaknya masih tercatat secara manual. Salah satu penyelesaian untuk meminimalisir pengelolaan informasi pendaftaran ekstrakurikuler dan data siswa agar lebih cepat, tepat, dan akurat dengan membuat aplikasi online. Karena pendaftaran masih menggunakan sistem manual, bisa menjadikan kendala dalam hal waktu dan biaya. dari masalah itu, dibuatnya aplikasi pendaftaran ektrakulikuler online yang dapat membantu siswa melakukan pendaftaran ekstrakurikuler di tingkat sekolah menegah pertama. Metode yang digunakan dalam perancangan aplikasi ini dengan metode waterfall dengan menggunakan bahasa pemrograman PHP (Hypertext Preprocessor).
\end{abstract}

Kata Kunci: aplikasi pendaftaran ektrakulikuler, online

\begin{abstract}
Every school must have a variety of non-formal formal activities or commonly called extracurricular activities that are useful for forming the student's own personality. There are many goals of extracurricular activities at school, one of which is to develop students' talents, interests, hobbies and skills in the effort of personal coaching towards full human coaching so as to create superior and reliable human resources. Besides that, if extracurricular activities can be carried out seriously, it is possible for students to achieve achievements by participating in competitions or championships starting from the local, national to international levels. The development of school education in managing data of students participating in extracurricular organization activities at least is still recorded manually. One solution is to minimize the management of extracurricular registration information and student data so that it is faster, more precise, and accurate by creating online applications. Because registration still uses a manual system, it can create obstacles in terms of time and money. from this problem, an online extracurricular registration application was made that could help students carry out extracurricular registration at the junior high school level. The method used in the design of this application with the waterfall method using the PHP programming language (Hypertext Preprocessor).
\end{abstract}

Keywords: extracurricular registration application, online

\section{PENDAHULUAN}

Pendidikan karakter sangat penting untuk generasi muda Indonesia karena generasi muda ini nantinya akan menjadi tombak pembangunan bangsa. Sebagai penerus bangsa diharapkan para generasi muda dapat memberikan teladan baik sikap maupun tingkah lakunya. Mereka bukan hanya harus pandai dan cerdas secara intelektual namun juga harus pintar dan cerdas dalam moralnya. Sebenarnya pendidikan karakter tidak hanya diberikan kepada generasi muda saja namun juga harus diberikan kepada seluruh warga Negara Indonesia demi tercapainya karakter bangsa yang sesuai dengan nilainilai pancasila (Yanti et al., 2016). Setiap sekolah pasti memiliki beragam kegiatan non-pelajaran formal atau biasa disebut ekstrakulikuler yang berguna untuk membentuk pribadi siswa. Ekstrakurikuler merupakan kegiatan pendidikan diluar jam pelajaran yang ditunjukkan untuk membantu perkembangan peserta didik, sesuai dengan kebutuhan, potensi, bakat, dan minat mereka melalui kegiatan yang secara khusus diselenggarakan 
oleh peserta didik dan atau tenaga kependidikan yang berkemampuan dan berkewenangan di sekolah(Wiyani, 2013).

Penelitian sebelumnya dilakukan oleh(Suryanto \& Ramadon, 2018) menyimpulkan bahwa perkembangan pendidikan sekolah dalam mengelola siswa yang mengikuti pendaftaran kegiatan organisasi ektrakulikuler di SMK Malaka Jakarta masih tercatat secara manual. Salah satu cara penyelsaian untuk meminimalisir pengelolaan informasi pendaftaran ektrakulikuler dengan membuat sistem informasi pendaftaran ektrakulikuler berbasis website.

Berdasarkan hasil observasi yang dilakukan di tingkat Sekolah Menengah Pertama (SMP) masalah yang ditemukan diantaranya: 1. Informasi tentang ekstrakulikuler di sekolah masih harus datang ke ruang organisasi. 2. Pendaftaran ekstrakulikuler di tingkat SMP masih sistem manual. Tujuan dari penelitian ini membangun suatu aplikasi yang cepat dan akurat untuk siswa dalam membantu dan memudahkan proses pendaftaran ektrakulikuler di tingkat SMP secara online.

Jika penelitian memiliki orisinalitas tinggi, yang mengusulkan metode atau algoritma baru, bab tambahan setelah "Pendahuluan" dan sebelum "Metode Penelitian" dapat ditambahkan untuk menjelaskan secara singkat metode atau algoritma yang diusulkan. Bab Pendahuluan juga dapat memuat teori-teori pendukung dari metode yang diusulkan untuk pemecahan suatu masalah dan/atau pengembangan dari metode tersebut, yang didasarkan referensi yang jelas (buku, jurnal, prosiding dan artikel ilmiah lainnya).

\section{Konsep Dasar Web}

Website atau yang di singkat web, dapat diartikan sekumpulan halaman yang terdiri atas beberapa laman yang berisi informasi dalam bentuk data digital, baik berupa teks, gambar, video, audio dan animasi lainnya yang disediakan melalui jalur koneksi internet(Abdulloh, 2016). Menurut (Wijaya, 2015) menyatakan bahwa "internet (Interconnected Network) adalah sebutan untuk jaringan komputer global yang 10 menghubungkan satu komputer dengan komputer lain yang ada di seluruh dunia". Dalam membangun sebuah website dibutuhkan Apache Server dan Phpmyadmin. Menurut (Abdulloh, 2016) bahwa, "Apache adalah aplikasi yang berfungsi sebagai web server, fungsinya sebagai tempat menyimpan file-file PHP (Hypertext Preprocessor) dan file-file lainya yang diperlukan website". Sedangkan Phpmyadmin menurut (Abdulloh, 2016) "adalah aplikasi berbasis web yang digunakan untuk membuat basis data (Database) MySQL sebagai tempat untuk menyimpan data-data website". Keduanya aplikasi tersebut sudah ada dalam paket aplikasi.

XAMPP adalah salah satu paket installer yang berisi Apache yang merupakan web server tempat menyimpan file-file yang diperlukan website, dan phpmyadmin sebagai aplikasi yang digunakan untuk perancangan database MySQL(Abdulloh, 2016).

\section{Bahasa Pemrograman}

Menurut (Abdulloh, 2016)menyatakan bahwa "Bahasa pemrograman merupakan Bahasa yang dapat dipahami oleh computer. Ada banyak Bahasa pemrograman yang memiliki fungsi berbeda-beda, di antaranya Bahasa pemrograman untuk membuat aplikasi desktop, membuat game, membuat aplikasi web, membuat aplikasi handphone, dan sebagainya."

PHP singkatan dari Hypertext Preprocessor yang merupakan server-side programming, yaitu bahasa pemrograman yang diproses di sisi server(Abdulloh, 2016). PHP berjalan pada sisi server sehingga PHP disebut juga sebagai bahasa Server Side Scripting. Artinya bahwa setiap/untuk menjalankan PHP, wajib adanya Web Server (Saputra, 2011).

CSS singkatan dari Cascading Style Shessts, yaitu skrip yang digunakan untuk mengatur desain website(Abdulloh, 2016). CSS memliki framework yang bernama Bootstrap yang berisi sekumpulan file CSS, font dan javascript yang siap diintegrasikan kesebuah dokumen HTML menggunakan kaidah tertentu(Subagia, 2018).

\section{Basis Data}

"Basis data adalah sebuah kumpulan data yang saling berhubungan secara logis, dan merupakan sebuah penjelasan dari data tersebut, yang didesain untuk menemukan data yang ditentukan oleh sebuah organisasi"(Indrajani, 2015). "basis data adalah sekumpulan fakta berupa reprensitasi table yang saling berhubungan dan disimpan dalam media penyimpanan secara digital"(Priyadi, 2014).

Perangkat lunak yang digunakan untuk mengelola basis data disebut dengan DBMS (Database Management System). Menurut (Trisyanto, 2017:122) bahwa, "DBMS adalah software yang menangani semua akses ke basis data". Salah satu perangkat lunak pengelola basis data adalah MySQL sebagai DBMS (Database Management System) pada penelitian ini.

\section{Pendaftaran}

Menurut KBBI (Kamus Besar Bahasa Indonesia) pendaftaran adalah proses, cara, perbuatan mendaftar (mendaftarkan). Pendaftaran juga berarti pencatatan nama, alamat, dan sebagainya dalam daftar.

\section{Ektrakulikuler}

Ekstrakurikuler merupakan kegiatan pendidikan diluar jam pelajaran yang ditunjukkan 
untuk membantu perkembangan peserta didik, sesuai dengan kebutuhan, potensi, bakat, dan minat mereka melalui kegiatan yang secara khusus diselenggarakan oleh peserta didik dan atau tenaga kependidikan yang berkemampuan dan berkewenangan di sekolah(Wiyani, 2013).

\section{Pendaftaran Ekstrakulikuler}

Berdasarkan penjelasan Pendaftaran dan Ekstrakulikuler bisa disimpulkan bahwa Pendaftaran Ekstrakulikuler adalah proses mendaftarkan diri pada kegiatan non-pelajaran formal yang pada umumnya kegiatan tersebut dilakukan diluar jam belajar kurikulum standar.

\section{Online}

Daring atau online dalam jaringan adalah terjemahan dari istilah online yang bermakna tersambung ke dalam jaringan komputer. Secara umum daring atau online menunjukan keadaan terhubung(Kemenristekdikti, 2017). Dalam KBBI (Kamus Besar Bahasa Indonesia) daring merupakan kependekan dari kata dalam jaringan. Secara tidak langsung online juga dapat diartikan sebagai suatu keadaan komputer yang dapat saling bertukar informasi karena sudah terhubung.

\section{Tools Analisis dan Desain Sistem}

UML (Unified Modelling Language) merupakan bahasa standar untuk membuat rancangan software untuk menggambarkan dan membangun dokumen artifak dari software intensive system(Booch, 2005)

\section{METODE PENELITIAN}

Metode penelitian yang dilakukan pada penelitian ini menggunakan model waterfall. Menurut (Sukamto \& Shalahuddin, 2018) menjelaskan bahwa model waterfall menyediakan pendekatan alur hidup perangkat lunak secara sekuensial atau terurut dimulai dari analis, desain, pengkodean, pengujian dan tahap pemeliharaan. Berikut lima fase model waterfall:

\section{Analisa}

Setelah penulis melakukan analisis kebutuhan yang berjalan di sistem, maka penulis menetapkan beberapa spesifikasi yang nantinya menjadi bahasan diantaranya: data konfirmasi pembayaran, data pendaftaran peserta dan data rekening bank.

2 Desain

Tahapan ini merupakan tahap dari suatu keperluan yang telah dianalisis ke dalam bentuk yang mudah dimengerti oleh pengguna melalui halaman front end dan back end. Perancangan dilakukan menggunakan ERD, LRS dan Struktur navigasi.

3 Pengkodean
Pada tahap pengkodean dilakukan dengan bahasa pemrograman PHP dengan menggunakan web editor Adobe Dreamweaver.

4 Pengujian

Perancangan perangkat lunak direalisasikan sebagai serangkaian program, pengujian unit melibatkan verifikasi. Bahwa program telah memenuhi spesifikasinya menggunakan Blackbox Testing.

5 Pemeliharaan

Program ini dibutuhkan antivirus untuk mencegah masuknya virus kedalam data yang telah dibuat. Selain itu perlu juga dilakukan penggantian kata sandi dalam jangka waktu tertentu agar user tidak dapat mengakses masuk atau login ke menu master ketika sedang tidak aktif. Dan perlu juga untuk menambahkan fitur pada program seiring berkembangnya pendaftaran siswa ekstrakulikuler tersebut.

Teknik pengumpulan data yang digunakan dalam penelitian ini diantaranya: 1. Observasi secara langsung mengenai kegiatan operasional system pendaftaran ektrakulikuler di tingkat SMP di beberapa wilayah Bekasi. 2. Studi pustaka dengan mengumpulkan buku-buku dan literatur artikel ilmiah yang berhubungan dengan permasalahan penelitian.

\section{HASIL DAN PEMBAHASAN}

\section{Activity Diagram Bussiness Process}

Activity Diagram Bussiness Process dari penelitian ini seperti pada Gambar 1.

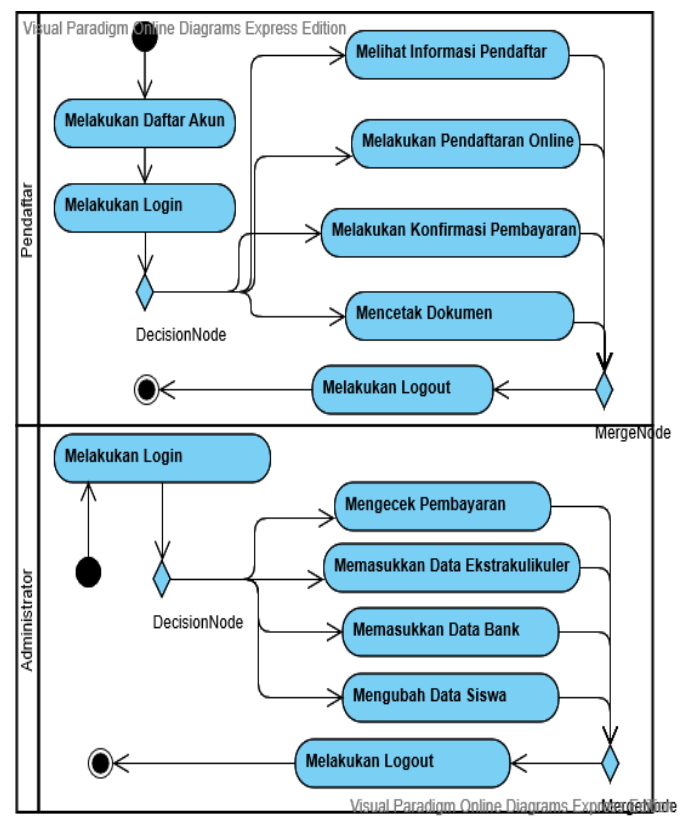

Sumber: Hasil Penelitian (2020)

Gambar 1. Activity Diagram Bussiness Process Aplikasi E-Ekskul di Tingkat SMP 


\section{Use Case Diagram}

Use Case Diagram pada penelitian ini memberikan gambaran antara use case, aktor dan sistem. use case diagram dari alur Aplikasi Pendaftaran Ektrakulikuler Online seperti pada Gambar 2.

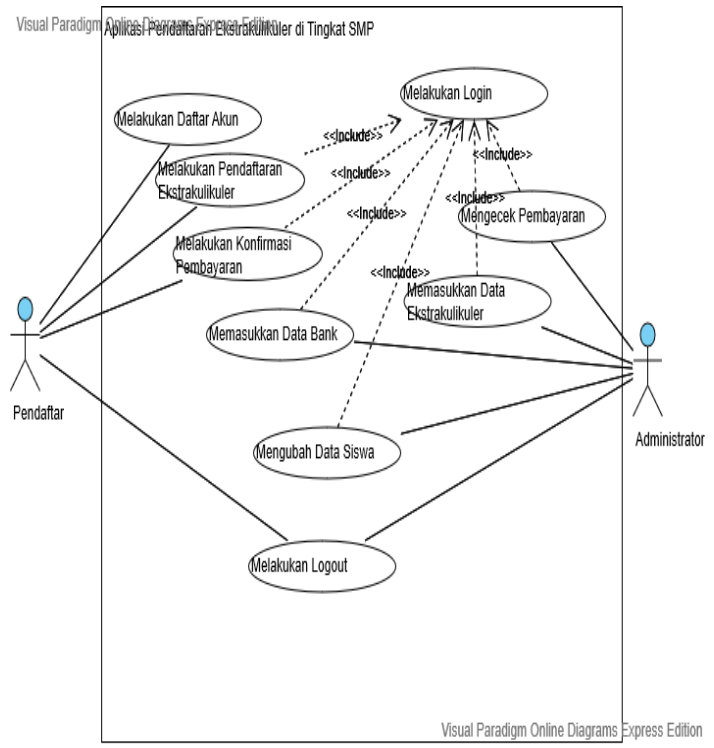

Sumber: Hasil Penelitian (2020)

Gambar 2. Aplikasi (E-Ekskul) di Tingkat SMP

Table 1. Use case diagram alur Pendaftar/Peserta Ekskul

\begin{tabular}{|c|c|}
\hline Use case & Pendaftar \\
\hline Actor & Pendaftar \\
\hline \multirow{9}{*}{$\begin{array}{l}\text { Brief } \\
\text { Description }\end{array}$} & $\begin{array}{lll}\text { Saat } & \text { Pendaftar } & \text { belum }\end{array}$ \\
\hline & $\begin{array}{l}\text { melakukan memiliki akun maka } \\
\text { tidak dapat login ke dalam } \\
\text { sistem dan wajib melakukan }\end{array}$ \\
\hline & $\begin{array}{l}\text { Daftar Akun } \\
\text { mendapatkan nomor peserta, } \\
\text { jika pendaftar sudah memiliki } \\
\text { akun maka pengguna dapat } \\
\text { melakukan aktifitas sebagai } \\
\text { berikut: }\end{array}$ \\
\hline & 1. Melihat Informasi Pendaftar \\
\hline & $\begin{array}{l}\text { 2. Melakukan Pendaftaran } \\
\text { Online }\end{array}$ \\
\hline & 3. Melakukan \\
\hline & Pembayaran \\
\hline & 4. Mencetak Dokumen \\
\hline & 5. Melakukan Logout \\
\hline Alternative & Jika pada saat login, Nomor \\
\hline Flow & $\begin{array}{l}\text { Peserta dan Kata Sandi salah } \\
\text { maka muncul kotak peringatan } \\
\text { dan kembali menuju halaman } \\
\text { login }\end{array}$ \\
\hline Postcondition & $\begin{array}{l}\text { Jika semua atau sebagian } \\
\text { aktifitas telah dilakukan maka } \\
\text { dapat menggunakan fitur logout } \\
\text { untuk keluar dari sistem }\end{array}$ \\
\hline
\end{tabular}

\section{Sequence Diagram}

Sequence Diagram pada proses Pendaftaran E-Ekskul seperti pada Gambar 3.

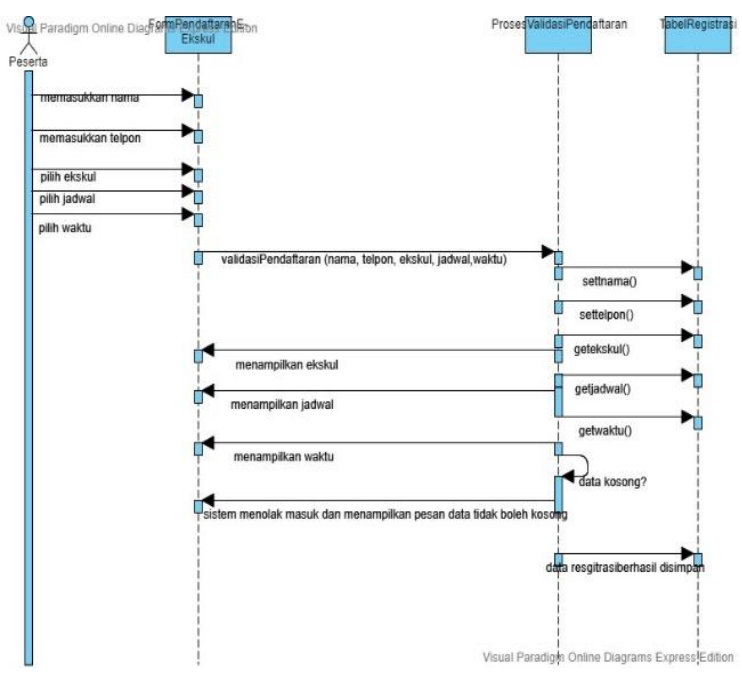

Sumber: Hasil Penelitian (2020)

Gambar 3. Sequence Diagram Proses Pendaftaran (E-Ekskul) di Tingkat SMP

\section{ERD}

Perancangan basis data pada aplikasi pendaftaran ekstrakulikuler online untuk tingkat SMP digambarkan dalam bentuk Entity Relationship Diagram (ERD) seperti Gambar 4.

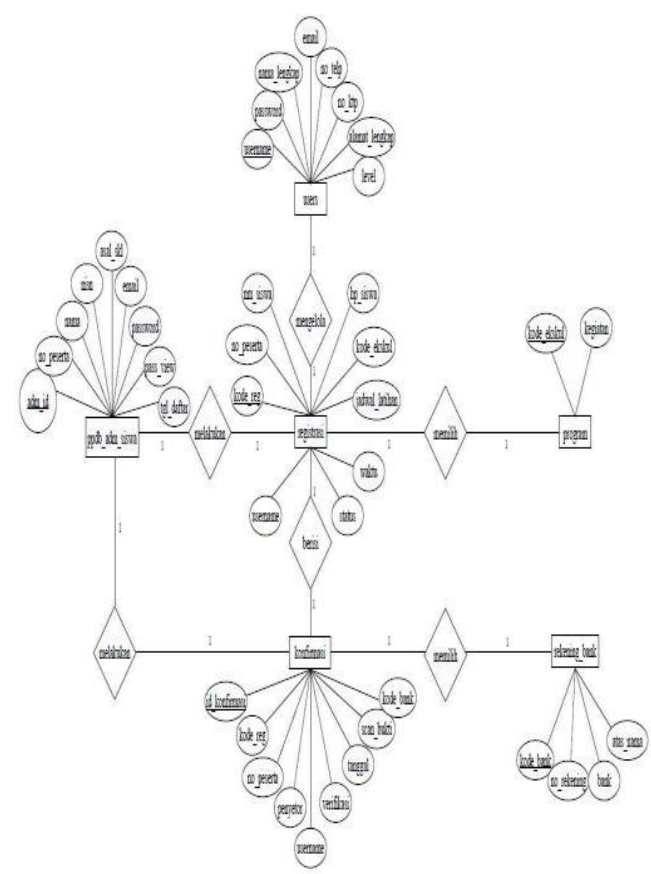

Sumber: Hasil Penelitian (2020)

Gambar 4. ERD Aplikasi Pendaftaran (E-Ekskul) di Tingkat SMP 


\section{LRS}

Sedangkan Logical Record Structure (LRS) yang dihasilkan dari aplikasi E-Ekskul untuk Tingkat SMP seperti Gambar 5.

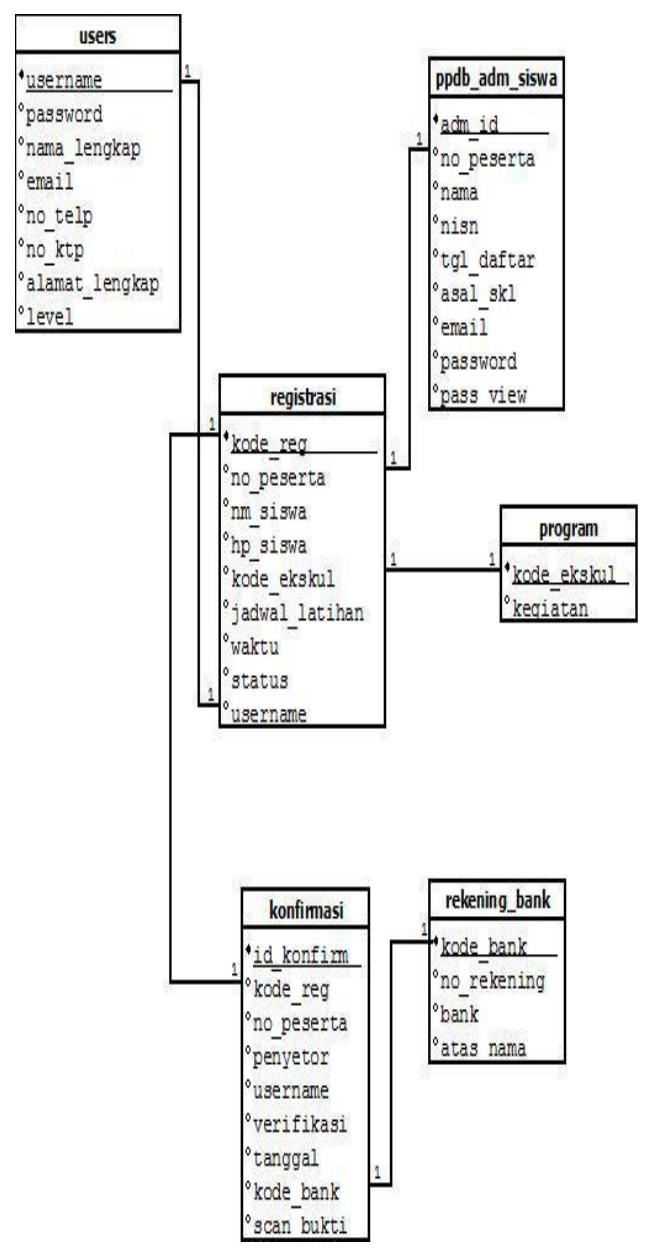

Sumber: Hasil Penelitian (2020)

Gambar 5. LRS dari Aplikasi E-Ekskul di Tingkat SMP

\section{Implementasi}

a. Implementasi Halaman Utama Aplikasi Pendaftaran Ektrakulikuler (E-Ekskul)

Halaman utama untuk publik ini terdiri dari menu Beranda, Informasi Peserta, Daftar Akun dan Login. Pada halaman publik ini dapat melihat informasi seputar peserta yang sudah mendaftar dan membuat akun untuk login ke menu Peserta seperti pada Gambar 6.

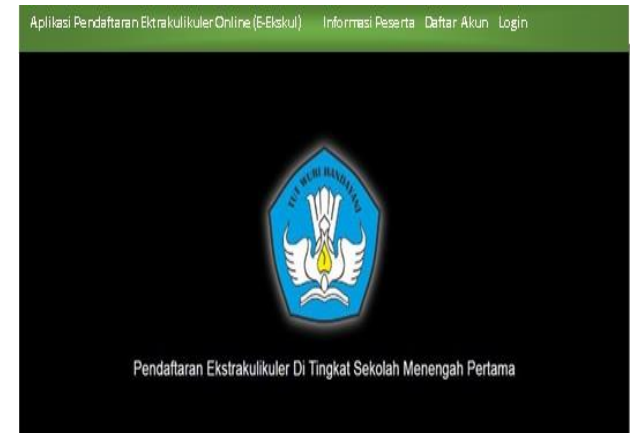

Sumber: Hasil Penelitian (2020)

Gambar 6. Menu Utama Aplikasi E-Ekskul

b. Membuat Akun Baru

Halaman membuat akun baru ini untuk pendaftar yang ingin mendaftar ekskul dan untuk mendapatkan nomor peserta seperti pada Gambar 7.

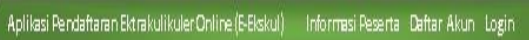

\section{Daftar Sebagai Peserta}

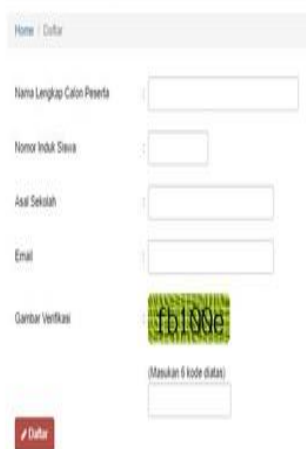

Sumber: Hasil Penelitian (2020)

Gambar 7. Halaman Daftar Akun Aplikasi E-Ekskul di Tingkat SMP

c. Implementasi Halaman Informasi Pendaftar

Halaman ini difungsikan sebagai pengumuman penerimaan atau penolakan para pendaftar seperti pada Gambar 8. 


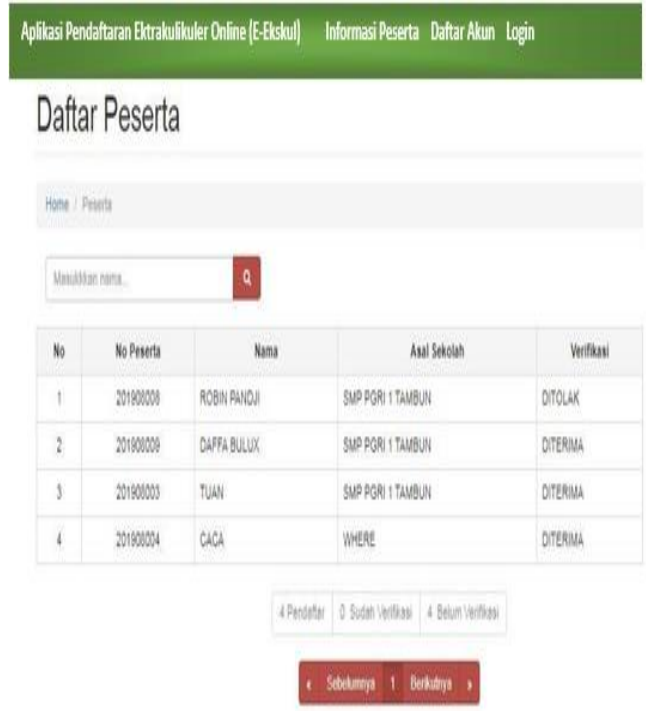

Sumber: Hasil Penelitian (2020)

Gambar 8. Halaman Informasi Peserta Aplikasi E-Ekskul

d. Implementasi Halaman Pendaftaran Online

Halaman ini digunakan pada saat pendaftar yang sudah membuat akun ingin masuk ke dalam sistem registrasi seperti pada Gambar 9.

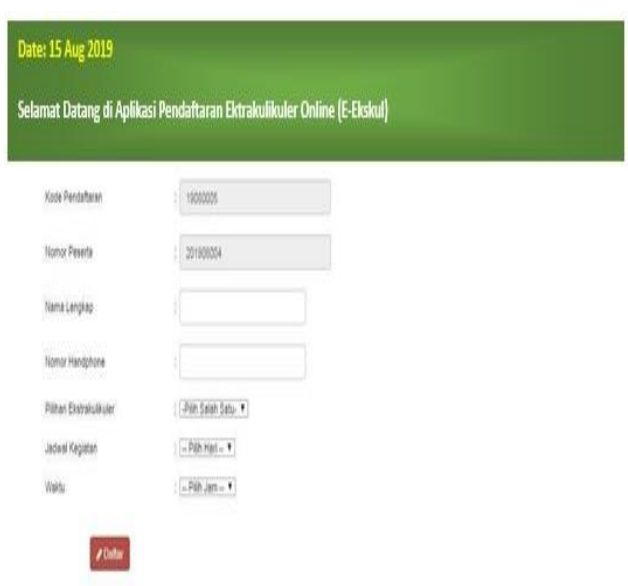

Sumber: Hasil Penelitian (2020)

Gambar 9. Halaman Pendaftaran Aplikasi E-Ekskul

e. Implementasi Halaman Konfirmasi Pembayaran
Halaman ini menampilkan konfirmasi pembayaran pendaftar harus menginput nama penyetor, pilihan bank serta mengupload bukti pembayaran seperti pada Gambar 10.
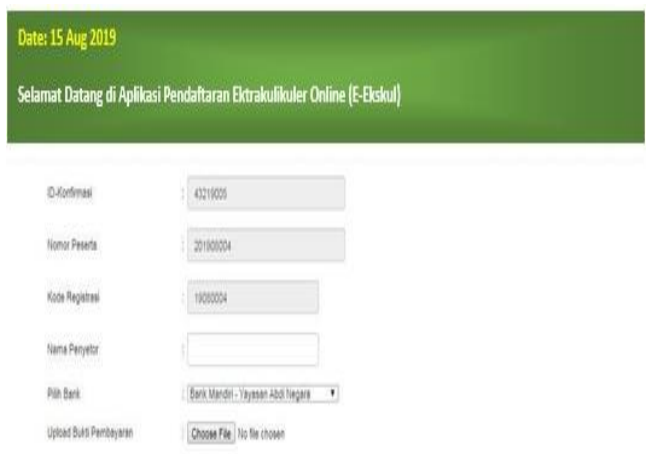

Sumber: Hasil Penelitian (2020)

$$
\begin{aligned}
& \text { Gambar 10. Halaman Konfirmasi } \\
& \text { Pembayaran Aplikasi E-Ekskul }
\end{aligned}
$$

\section{KESIMPULAN}

Aplikasi pendaftaran ekstrakurikuler online (EEkskul) di tingkat sekolah menengah pertama memberikan kemudahaan dalam proses pendaftaran ekskul dan menjadi alternative pilihan utama bagi para calon pendaftar yang dapat diakses secara online. Aplikasi E-Ekskul menjadi sarana untuk pembina ekstrakurikuler dalam memperluas jangkauan promosi dan sebagai media promosi serta memberikan citra yang bagus untuk sekolah perihal kemajuan sistem pendaftaran ekstrakurikuler.

\section{REFERENSI}

Abdulloh, R. (2016). Easy \& Simple Web Programming. PT Elex Media Komputindo.

Booch, G. (2005). Object Oriented Analysis and Design with Application 2nd Edition.

Indrajani. (2015). Perancangan Basis Data dalam All in 1. Elex Media Komputindo.

Kemenristekdikti. (2017). Buku Panduan Pengisian Survei Pembelajaran Dalam Jaringan.

Priyadi, Y. (2014). Kolaborasi SQL dan ERD Dalam Implementasi Database. Andi.

Saputra, A. (2011). Trik dan Solusi Pemprograman PHP. PT Elex Media Komputindo.

Subagia, A. (2018). Membangun Aplikasi Web Dengan Metode OOP. PT.Elex Media 
Komputindo.

Sukamto, R. A., \& Shalahuddin, M. (2018). Rekayasa Perangkat Lunak (Revisi). Informatika.

Suryanto, A., \& Ramadon. (2018). Perancangan Sistem Informasi Pendaftaran Ekstrakurikuler Berbasis Web Pada SMK Malaka Jakarta. Paradigma, $X X(2)$, 57-62.

Wijaya, G. (2015). Internet Untuk Pemula: Panduan Cepat Dan Mudah Belajar Internet. Familia.

Wiyani, N. A. (2013). Menumbuhkan Pendidikan Karakter di SD (Konsep, Praktek dan Strategi). Ar-Ruzz Media.
Yanti, N., Adawiah, R., \& Matnuh, H. (2016). Pelaksanaan Kegiatan Ekstrakurikuler Dalam Rangka Pengembangan Nilai-Nilai Karakter Siswa Untuk Menjadi Warga Negara Yang Baik Di Sma Korpri Banjarmasin. Jurnal Pendidikan Kewarganegaraan, 6, 963-970. https://media.neliti.com/media/publications/12 0795-ID-pelaksanaan-kegiatanekstrakurikuler-dal.pdf 